\title{
Data mining analysis of mir-638 and key genes interaction in cisplatin resistant triple-negative breast cancer
}

\author{
Adam Hermawan ${ }^{1, *}$, Herwandhani Putri ${ }^{2}$ \\ ${ }^{1}$ Laboratory of Macromolecular Engineering, Department of Pharmaceutical Chemistry, Faculty of Pharmacy, Universitas Gadjah Mada, \\ Sekip Utara II, Yogyakarta 55281, Indonesia \\ ${ }^{2}$ Cancer Chemoprevention Research Center, Faculty of Pharmacy, Universitas Gadjah Mada, Sekip Utara II, Yogyakarta 55281, Indonesia \\ *Corresponding author: adam_apt@ugm.ac.id
}

SUBMITTED 14 August 2019 REVISED 9 October 2019 ACCEPTED 12 November 2019

\begin{abstract}
Cisplatin is one of the chemotherapy for the treatment of triple-negative breast cancer (TNBC), but its effectiveness is limited because of the phenomenon of chemoresistance. miR-638 was shown to regulate chemoresistance; however, it has never been validated in the cisplatin-resistant tumor from patients. This present study aimed to identify the key gene regulatory networks of miR-638 and evaluate the potential role of the miR-638 and its targets as potential prognosis biomarkers for cisplatin-resistance triple-negative breast cancer patients. The miR-638 target was obtained from the miRecords database while the mRNA of chemoresistance biomarker candidate was obtained from the GSE18864 of GEO database, which is mRNA of cisplatin-resistance TNBC patients. CCND1 and FZD7 are potential candidates for cisplatin chemoresistance biomarkers in patients with TNBC. Moreover, a Kaplan-Meier survival plot showed that breast cancer patients with low mRNA levels of FZD7 had significantly worse overall survival than those in higher mRNA expression group. Taken together, miR-638 plays a role in cisplatin resistance mechanism through a mechanism involving its target gene CCND1 and FZD7. Overall, miR-638, CCND1, and FZD7 are candidates for cisplatin biomarker resistance in TNBC.
\end{abstract}

KEYWORDS miR-638; chemoresistance; triple-negative breast cancer; data mining

\section{Introduction}

Triple-negative breast cancer (TNBC) occurs in about $20 \%$ of cases of breast cancer and is associated with the risk of relapse and poor prognosis (Kuo et al. 2017). Cisplatin is a chemotherapy drug, which is used for the treatment of triple-negative breast cancer, but its effectiveness has not been maximized due to the problem of chemoresistance (Hu et al. 2015). Chemoresistance is a phenomenon when cancer cells become insensitive to chemotherapy and are classified into intrinsic and acquired resistance (Ji et al. 2019). The TNBC is an aggressive subtype that usually evolves chemoresistance (Kim et al. 2018). One of the biomarkers for predicting chemoresistance and prognosis is miRNA (Wei et al. 2019), a small non-coding RNA consisting of 21-22 nucleotides that negatively target mRNA, and thus suppresses the expression of its target genes (Orso et al. 2019).

miR-638 is one of the miRNAs that has been extensively investigated in the development of cancer ( $\mathrm{Li}$ et al. 2011; Lin et al. 2015; Wei et al. 2017). It acts as either a tumor suppressor gene or oncogene. miR-638 possesses a tumor suppressor gene by inducing apoptosis and inhibit- ing cell proliferation, invasion, and migration (Shen et al. 2017). In osteosarcoma, miR-638 promotes apoptosis by suppressing cyclin D1, phospholipase D1 (PLD1) and vascular endothelial growth factor (VEGF) (Xue et al. 2019). miR-638 directly targets HOXA9 and suppresses the expression of Wnt/beta-catenin-regulated oncogenes cyclin D1 and C-MYC (Zheng et al. 2018). On the other hand, miR-638 acts as an oncogene. miR-638 promotes metastasis and prevents cell death in melanoma cells (Bhattacharya et al. 2015). It induces cell proliferation, migration, and invasion in oesophagal squamous cell carcinoma and breast cancer cells by targeting DACT3, a key regulator of Wnt/beta-catenin signaling (Ren et al. 2017).

miR-638 also regulates chemoresistance in cancer cells. Increasing expression of miR-638 after chemotherapy in non-small cell lung cancer patients is correlated with better survival (Wang et al. 2015). It also enhances the efficacy of bleomycin and cisplatin in K562 leukemic cells (He et al. 2016). In MDA-MB231 cells, miR-638 regulates cell migration and sensitivity to cisplatin (Tan et al. 2014). Nevertheless, no study has been conducted on the regulation of miR-638 and its regulatory network in cisplatin-resistant TNBC using patient samples.

Over the past few years, bioinformatics has grown and 
provided new methods for the prediction of drug-target genes using multiplatform analysis (Wang et al. 2019). Computational approaches have been used to mine and integrate data in public databases to provide researchers with accurate and fast information in the field of biomedicine and drug discovery (Pandika 2018). In this study, several databases were used, including GEO, TargetScan, ONCOMINE, KMPlotter, STRING, and c-Bioportal to identify the interactions between miR-638 and its target genes in patients with cisplatin-resistance TNBC.

In this study, we utilize a bioinformatics approach with data mining analysis to identify key gene regulatory networks of miR-638 and evaluate the potential role of the miR-638 and its targets as potential prognosis biomarkers for cisplatin-resistance triple-negative breast cancer patients. The target of miR-638 was predicted using miRecords database. Gene expression profile of cisplatinresistant breast cancer was obtained from GEO datasets. We also performed validation using KM Plot and ONCOMINE and identified genetic alterations among target genes in cBioportal database.

\section{Materials and Methods}

\subsection{Data collection and processing}

Microarray data were obtained from GSE18864, which contains twenty-eight women with triple-negative breast cancer stage II or III, which received four cycles of cisplatin. Patient age ranged from 29 to 69 years at diagnosis. Fourteen patients were considered a good response, and fourteen patients were considered as a poor response based on Miller-Payne score (Silver et al. 2010). Data processing was conducted using GEO2R, an online tool for GEO data analysis based on the R programming language (https://www.ncbi.nlm.nih.gov/geo/geo2r/). Differential expression genes (DEGs) between cisplatin sensitive and resistant cells/tissues were screened. Adjusted $\mathrm{P}$ value $<0.05$ and IFCI $>1.5$ were used to select significant DEGs, as described in a previous study (Zhao et al. 2018).

\section{2. miRNA target prediction}

The target of miR-638 was predicted using miRecords database (http://c1.accurascience.com/miRecords/) (Xiao et al. 2009). The target genes, predicted from at least four databases, were selected and collected. A Venn diagram was generated to DEGs from GSE18864 and miR-638 target genes from miRecords using Venny 2.1 (https://bi oinfogpcnbcsices/tools/venny/indexhtml) (Oliveros 2007) (Oliveros 2007). Interaction between miR-638 and its target genes in target sites was analyzed by TargetScan (http://www.targetscan.org) (Agarwal et al. 2015).

\subsection{Analysis of miR-638-target gene regulatory net- work}

miR-638-target gene (SRGAP1, HIC2, CCND1, $S A P 30 B P$, and FZD7) regulatory network was constructed with Cytoscape software (version 3.7.1) by using default parameters (Shannon et al. 2003).

\subsection{Kaplan Meier survival analysis}

The prognostic value of miR-638 and the target genes (SRGAP1, HIC2, CCND1, SAP30BP, and FZD7) were evaluated using Kaplan-Meier survival curves (http://kmplot.c om) by log-rank test, with $\mathrm{p}<0.05$ was selected as the cutoff value (Gyorffy et al. 2010).

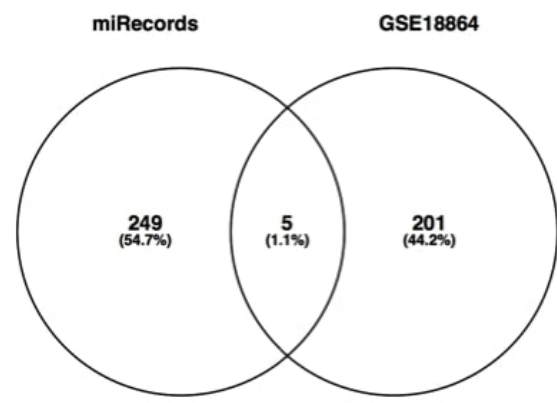

(a)

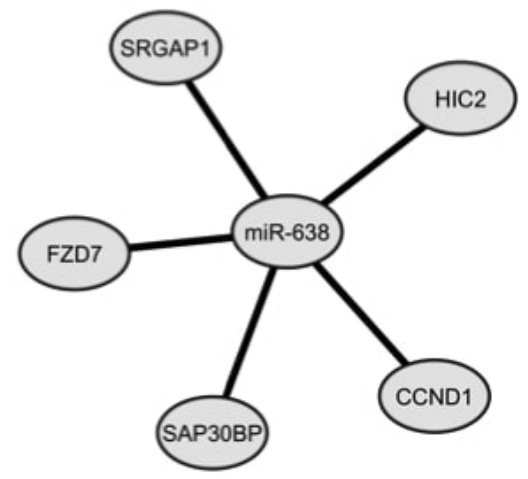

(b)

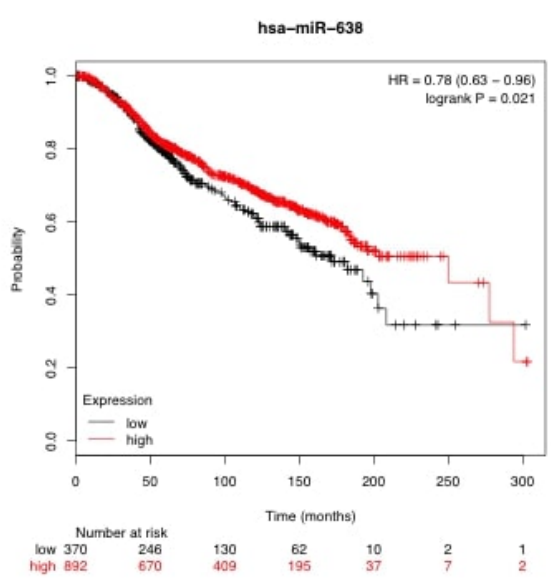

(c)

FIGURE 1 (a) Venn diagram of miR-638 target genes analyzed by miRecords and GSE18864; (b) miRNA 638-target gene regulatory network in cisplatin-resistant triple negative breast cancer, constructed by Cytoscape; (c) Overall survival curve of breast cancer patients related to the expression of miR-638. 
TABLE 1 Analysis of mutual exclusivity among target genes in the MBC study.

\begin{tabular}{lllll}
\hline Gene A & Gene B & p-Value & Log2 Odds Ratio & Tendency identification \\
\hline CCND1 & SAP30BP & $<0.001$ & 2.273 & Co-occurrence \\
SRGAP1 & CCND1 & 0.008 & 1.76 & Co-occurrence \\
SRGAP1 & SAP30BP & 0.014 & 2.052 & Co-occurrence \\
SAP30BP & FZD7 & 0.105 & $>3$ & Co-occurrence \\
HIC2 & SAP30BP & 0.2 & $>3$ & Co-occurrence \\
CCND1 & FZD7 & 0.308 & $>3$ & Co-occurrence \\
HIC2 & CCND1 & 0.522 & 1.179 & Co-occurrence \\
SRGAP1 & HIC2 & 0.83 & $<-3$ & Mutual exclusivity \\
SRGAP1 & FZD7 & 0.911 & $<-3$ & Mutual exclusivity \\
HIC2 & FZD7 & 0.992 & $<-3$ & Mutual exclusivity \\
\hline
\end{tabular}

\subsection{Validation of target genes in cisplatin-resistant and sensitive breast cancer cells}

Confirmation of the reliability of the target genes in cisplatin sensitive and resistant breast cancer cells was conducted using ONCOMINE (https://www.oncomine.org), a cancer microarray database and web-based data-mining platform (Rhodes et al. 2004). Briefly, the expression level of SRGAP1, HIC2, CCND1, SAP30BP, and FZD7 among cisplatin resistance breast cancer studies were retrieved from ONCOMINE.

\subsection{Analysis of genetic alterations among target genes}

The genetic alterations of target genes were analyzed from breast cancer studies using cBioPortal (http://www.cbiopo rtal.org) (Cerami et al. 2012; Gao et al. 2013). Screened target genes (SRGAP1, HIC2, CCND1, SAP30BP, and FZD7) were subjected to genetic alterations analysis in all breast cancer studies. The breast cancer study with the highest genetic alterations was chosen for mutual exclusivity of the screened target genes with $\mathrm{p}<0.05$ was selected as the cutoff value.

\section{SRGAP1}

\begin{tabular}{|c|c|c|c|c|c|c|c|}
\hline & $\begin{array}{c}\text { Predicted consequential paling of target region (top) } \\
\text { and mIRNA (bottom) }\end{array}$ & $\begin{array}{l}\text { She } \\
\text { type }\end{array}$ & $\begin{array}{c}\text { Context++ } \\
\text { score }\end{array}$ & $\begin{array}{l}\text { Context++ score } \\
\text { percentlle }\end{array}$ & $\begin{array}{c}\text { Welghted } \\
\text { context+t score }\end{array}$ & $\begin{array}{c}\text { Conserved branch } \\
\text { length }\end{array}$ & Pet \\
\hline $\begin{array}{l}\text { Position 523-530 of SRGAP1 3' UTR } \\
\text { hsa-miR-638 }\end{array}$ & $\begin{array}{c}5^{\prime} \quad \text {...AUUGUCUCCAUGGGACGAUCCCA... } \\
\text { IIIIIIII } \\
3^{\prime} \quad \text { UCCGGCGGUGGGCGGGCGCUAGGGA }\end{array}$ & 8mer & -0.10 & 64 & -0.08 & 0.072 & N/A \\
\hline
\end{tabular}

\section{HIC2}

\begin{tabular}{|c|c|c|c|c|c|c|c|}
\hline & $\begin{array}{l}\text { Predicted consequentlal pairing of target reglon (top) and } \\
\text { mIRNA (bottom) }\end{array}$ & $\begin{array}{l}\text { Site } \\
\text { typo }\end{array}$ & $\begin{array}{c}\text { Context++ } \\
\text { score }\end{array}$ & $\begin{array}{l}\text { Context++ score } \\
\text { percentlile }\end{array}$ & \begin{tabular}{|} 
Wolghted context++ \\
score
\end{tabular} & $\begin{array}{c}\text { Conserved branch } \\
\text { longth }\end{array}$ & Pet \\
\hline $\begin{array}{l}\text { Position 1988-1994 of HIC2 3' UTR } \\
\text { hsa-miR-638 }\end{array}$ & $\begin{array}{ll}5^{\prime} & \text {...AGCCCUCCCUGUGGUGAUCCCAG... } \\
3^{\prime} & \text { III IIIIII } \\
\text { UCCGGCGGUGGGCGGGCGCUAGGGA }\end{array}$ & $\begin{array}{c}7 \text { mer- } \\
\text { A1 }\end{array}$ & -0.16 & 77 & -0.03 & 0.048 & N/A \\
\hline
\end{tabular}

\section{CCND1}

\begin{tabular}{|c|c|c|c|c|c|c|c|}
\hline & $\begin{array}{l}\text { Predicted consequentlal pairing of target region (top) } \\
\text { and mIRNA (bottom) }\end{array}$ & $\begin{array}{l}\text { Site } \\
\text { type }\end{array}$ & $\begin{array}{c}\text { Context+4 } \\
\text { score }\end{array}$ & $\begin{array}{l}\text { Context++score } \\
\text { percentlie }\end{array}$ & $\begin{array}{c}\text { Welghted } \\
\text { context++ score }\end{array}$ & $\begin{array}{l}\text { Conserved branch } \\
\text { length }\end{array}$ & Рct \\
\hline $\begin{array}{l}\text { Position 2289-2296 of CCND1 3' UTR } \\
\text { hsa-miR-638 }\end{array}$ & $\begin{array}{l}5^{\prime} \quad \text {...GCAGACACGCGGGCGCGAUCCCA } \ldots \\
\text { IIIIIIII } \\
3^{\prime} \quad \text { UCCGGCGGUGGCGGGCGCUAGGA }\end{array}$ & 8mer & -0.19 & 84 & -0.18 & 0.031 & \\
\hline
\end{tabular}

\section{SAP30BP}

\begin{tabular}{|c|c|c|c|c|c|c|c|}
\hline & $\begin{array}{l}\text { Predicted consequential pairing of target reglon (top) } \\
\text { and mIRNA (bottom) }\end{array}$ & $\begin{array}{l}\text { Site } \\
\text { type }\end{array}$ & $\begin{array}{c}\text { Context+4 } \\
\text { score }\end{array}$ & $\begin{array}{l}\text { Context++ score } \\
\text { percentlle }\end{array}$ & $\begin{array}{c}\text { Wolghted } \\
\text { context++ score }\end{array}$ & $\begin{array}{l}\text { Conserved branch } \\
\text { length }\end{array}$ & Рст \\
\hline $\begin{array}{l}\text { Position 486-492 of SAP30BP 3' UTR } \\
\text { hsa-miR-638 }\end{array}$ & $\begin{array}{l}5^{\prime} \quad \text {...CCCAUCUGCCGCCUU-GAUCCCAA... } \\
\quad 11111 \text { IIIIIII } \\
3^{\prime} \quad \text { UCCGGCGGUGGGCGGGCGCUAGGGA }\end{array}$ & $\begin{array}{c}7 \mathrm{mer}- \\
\mathrm{A} 1\end{array}$ & -0.27 & 94 & -0.20 & 0.071 & V/A \\
\hline
\end{tabular}

\section{FZD7}

\begin{tabular}{|c|c|c|c|c|c|c|c|}
\hline & $\begin{array}{l}\text { Predicted consequential pairing of target region (top) and } \\
\text { mIRNA (bottom) }\end{array}$ & $\begin{array}{l}\text { Site } \\
\text { type }\end{array}$ & $\begin{array}{c}\text { Context++ } \\
\text { score }\end{array}$ & $\begin{array}{l}\text { Context++ score } \\
\text { percentile }\end{array}$ & $\begin{array}{l}\text { Welghted context++ } \\
\text { score }\end{array}$ & $\begin{array}{l}\text { Conserved branch } \\
\text { length }\end{array}$ & $\mathrm{P}_{\mathrm{CT}}$ \\
\hline $\begin{array}{l}\text { Position } 356-362 \text { of FZD7 3' UTA } \\
\text { hsa-miR-638 }\end{array}$ & $\begin{array}{l}5^{\prime} \quad \text {...AACGGGGACUGUGAGCGAUCCCC... } \\
\text { IIIIIII } \\
\text { 3. } \\
\text { UCCGGCGGUGGGCGGGCGCUAGGGA }\end{array}$ & $\begin{array}{c}7 \mathrm{mer}- \\
\mathrm{m} 8\end{array}$ & -0.08 & 57 & -0.08 & 0 & \\
\hline
\end{tabular}

FIGURE 2 miR-638-target gene interactions, analyzed by TargetScan. 


\section{Results}

\subsection{Identification of miR-638 target genes and miR- 638-target gene regulatory network}

A total of 254 and 206 genes were extracted from miRecords and GSE18864, respectively (Figure 1a). A Venn diagram generated five DEGs from miRecords and GSE18864, including SRGAP1, HIC2, CCND1, SAP30BP, and FZD7. A miR-638 target gene regulatory network was constructed (Figure $1 \mathrm{~b}$ ). Interaction between miR-638 and its target genes in target sites was analyzed by TargetScan (Figure 2).

\subsection{Kaplan Meier survival analysis}

Kaplan Meier plot for overall survival of breast cancer patients showed that patients with the high miR-638 level had significantly worse overall survival than those in the low expression level group ( $p=0.021$ ) (Figure 1c). The overall survival was also obtained according to the low and high expression levels of each target gene (Figure 3). The results showed that patients with the high mRNA level of $S R$ GAP1 ( $\mathrm{p}=0.13)$, CCND1 $(\mathrm{p}=0.18)$, and FZD7 $(\mathrm{p}=0.046)$ (Figure 3 ) have better survival than patients with the low
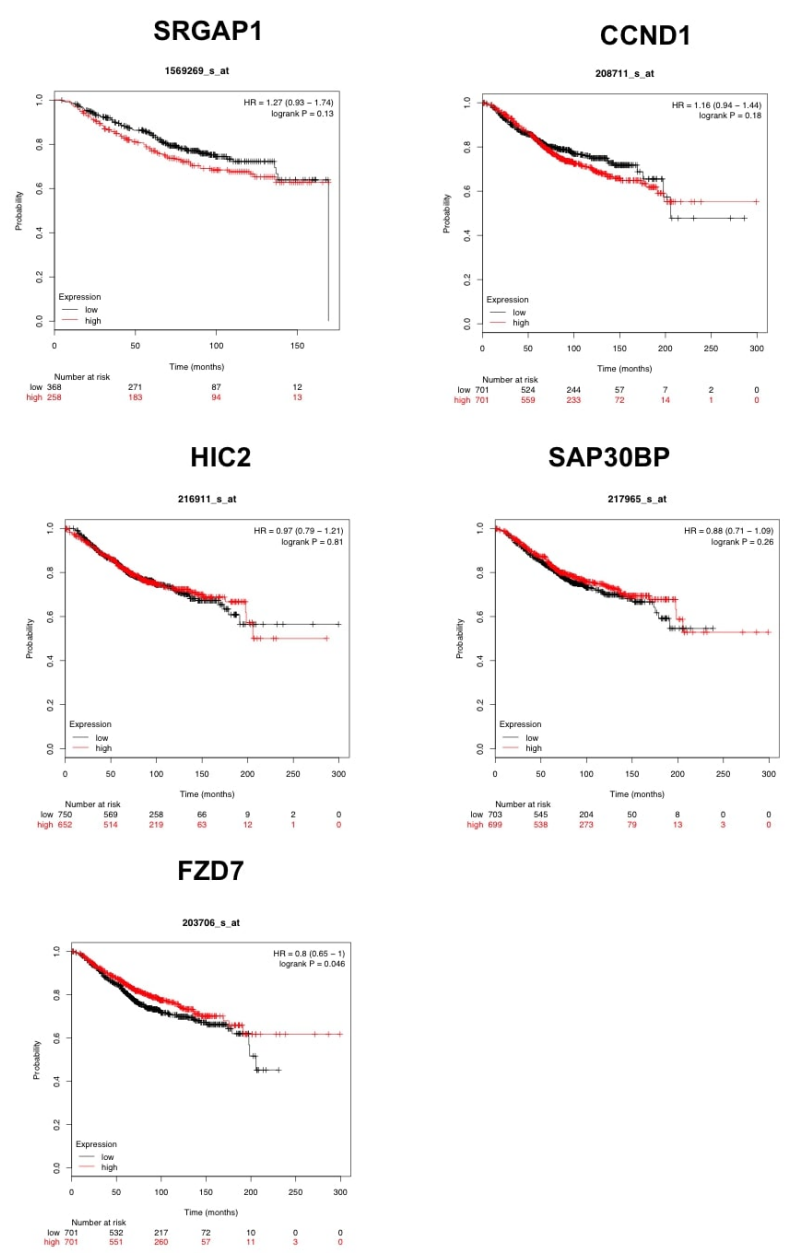

FIGURE 3 Overall survival of SRGAP1, HIC2, CCND1, SAP3OBP, and FZD7 across breast cancer samples, analyzed by KMPlotter.

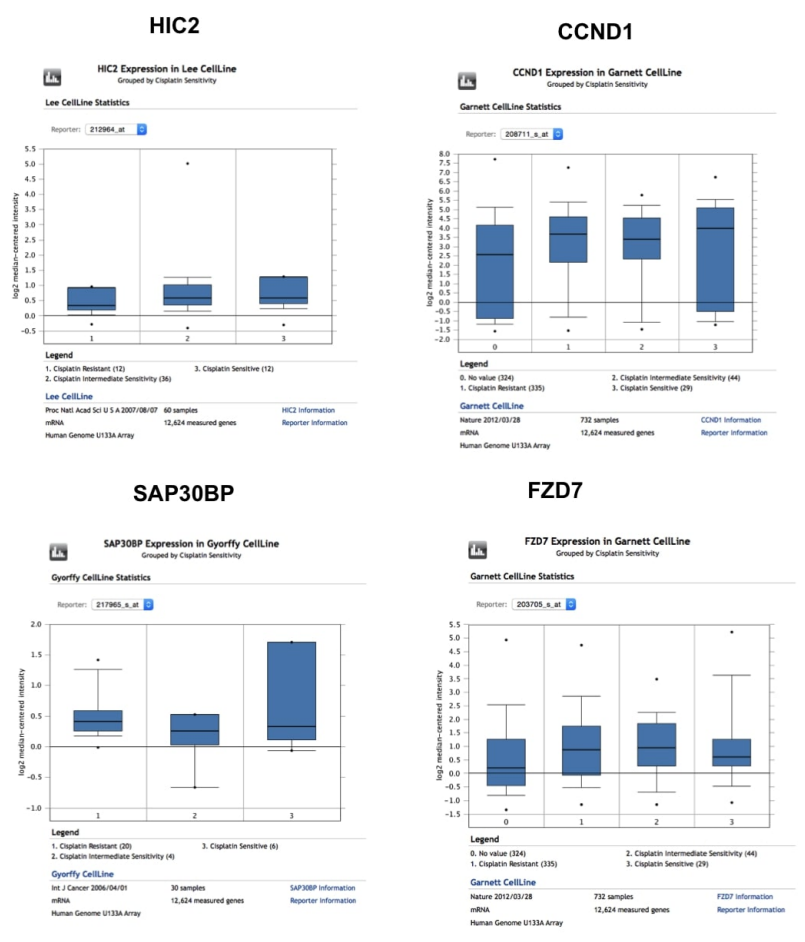

FIGURE 4 Expression of HIC2, CCND1, SAP30BP, and FZD7 across cisplatin-resistant breast cancer samples, analyzed by ONCOMINE.

mRNA level. Moreover, patients with the high mRNA level of HIC2 $(\mathrm{p}=0.81)$ and SAP30BP $(\mathrm{p}=0.26)$ have worse survival than those with the low mRNA level.

\subsection{Validation of target genes in cisplatin-resistant and sensitive breast cancer cells}

ONCOMINE was used to confirm the reliability of the target genes in cisplatin sensitivity (Figure 4). A study using cell lines showed the downregulation of HIC2 in cisplatinresistance breast cancer cells (Lee et al. 2007). Another study showed a similar level of CCND1 among cisplatinresistant and cisplatin-sensitive breast cancer cells (Garnett et al. 2012). A study showed the downregulation of SAP30BP cisplatin-resistance breast cancer cells (Gyorffy et al. 2006). Moreover, a study using cell lines showed a similar expression level of FZD7 among cisplatinsensitive and cisplatin-resistance breast cancer cells (Garnett et al. 2012). No study was found in ONCOMINE related to SRGAP1 and cisplatin resistance in breast cancer.

\subsection{Analysis of genetic alterations among target genes}

Five target genes (SRGAP1, HIC2, CCND1, SAP30BP, and FZD7) were analyzed using cBioportal to explore their genomic alterations across breast cancer studies. A study, namely the MBC Project (Lefebvre et al. 2016), showed the highest genetic alterations among breast cancer studies and was selected for further analysis (Figure $5 a)$. Genetic alterations for each target genes were found from 0.6\% (FZD7), 1.1\% (HIC2), 11\% (SRGAP1), 13\% (SAP30BP) and 35\% (CCND1) (Figure 5b). Moreover, most gene alterations belonged to amplification (Figure 


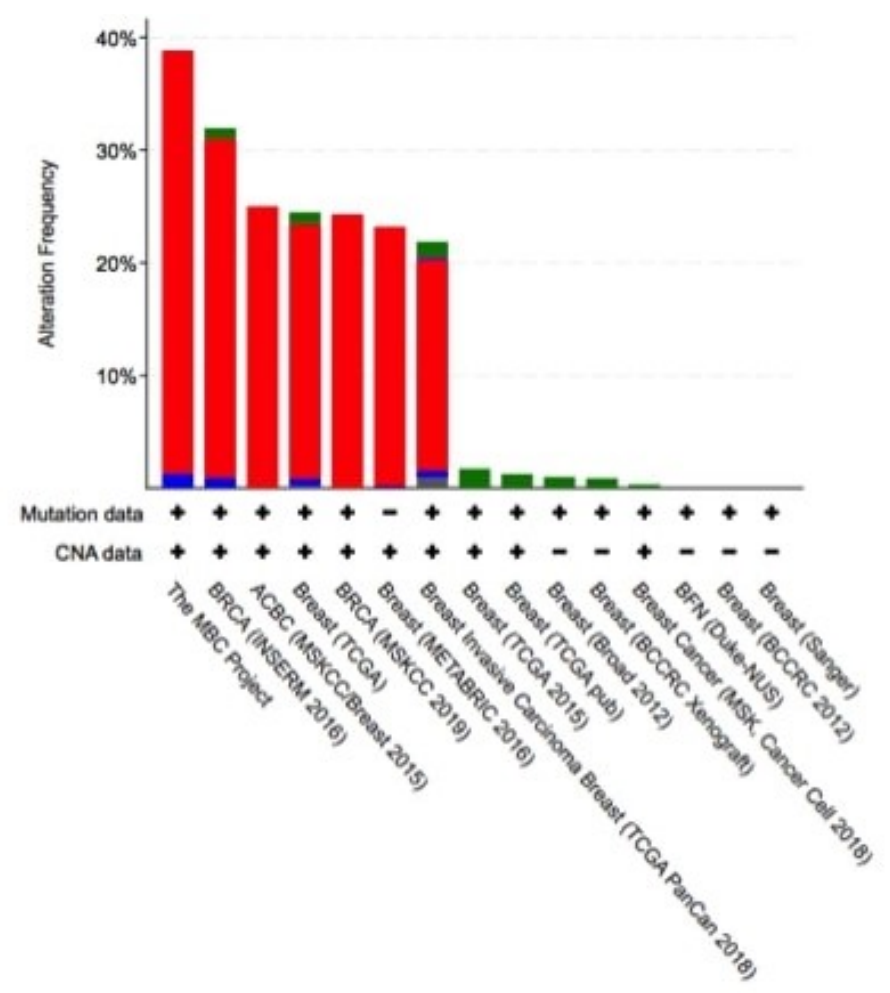

- Mutation - Fusion - Amplification - Deep Deletion - Multiple Alterations

(a)

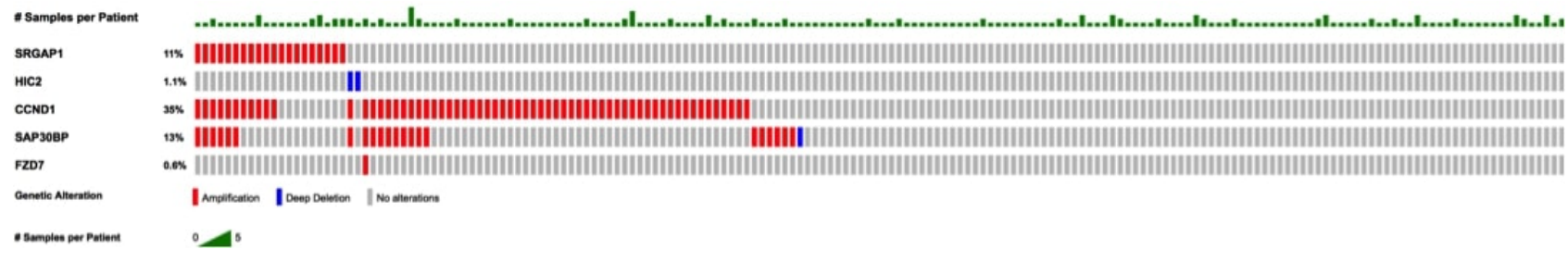
(b)

FIGURE 5 Summary of alterations for hub genes in breast cancer patients (a) Based on breast cancer study; (b) Genetic alterations of SRGAP1, HIC2, CCND1, SAP30BP, and FZD7 based on a study by Lefebvre et al. (2016).

5b). Additional mutual exclusivity showed that only three gene pairs (CCND1-SAP30BP, SRGAP1-CCND1, and SRGAP1-SAP30BP) exhibited significant co-occurrence $(\mathrm{p}<0.05)$ in breast cancer study by the MBC Project (Table 1).

\section{Discussion}

This present study aimed to identify the key gene regulatory networks of miR-638 and evaluate the potential role of the miR-638 and its targets as potential prognosis biomarkers for cisplatin-resistant TNBC patients. Understanding the relevance of miRNA and its mRNA target is very important to elucidate the mechanism of gene transcription and cellular pathophysiology. In addition, understanding the mechanism of resistance is very important for diagnosis and treatment in TNBC patients because this sub-type is hard to treat.

In this present study, five genes were identified from miRecords and GSE18864. Based on Kaplan Meier overall survival (Figure 3) and validation of target genes in cisplatin-resistant and sensitive breast cancer cells with ONCOMINE (Figure 4), two potential biomarkers were identified, which are CCND1 and FZD7. Genetic alterations analysis among samples from the MBC Project (Lefebvre et al. 2016) showed genetic alterations of CCND1 and FZD7 in 35\% and $0.6 \%$ of samples, respectively (Figure 5). Thus, CCDN1 and FZD7 are the potential key genes in cisplatin-resistant TNBC.

The two biomarker candidates, CCND1 and FZD7, are extensively studied for its regulation in cancer development. CCND1 encodes cyclin D1, which plays a role in cell cycle progression in the G1-S phase transition (Seiler et al. 2014). Cyclin D1 plays a role in the process of cell proliferation and growth regulation, DNA repair, cell 
migration, and a prognostic and predictive marker in different types of cancer (Ramos-Garcia et al. 2017). Cyclin D1 is frequently overexpressed in human cancers, including breast cancer (Maia et al. 2016), cervical cancer (Xu et al. 2016), and non-small cell lung cancer (Baykara et al. 2017). Cytoplasmic level of cyclin D1 is used for a biomarker of early diagnosis in breast cancer (Ullah Shah et al. 2015), as well as for biomarkers of invasiveness in endometrial, breast, prostate and colon cancer (Fuste et al. 2016). However, high expression of Cyclin D1 has a positive correlation with the beneficial effect of chemotherapy in metastatic bladder cancer (Seiler et al. 2014).

Genetic alterations study with cBioportal revealed alterations of CCND1 in 35\% of patient samples, with amplification as the highest alterations. Previous studies demonstrated that amplification in CCND1 is an early event in the development of a breast cancer stem cells (Burandt et al. 2016), and mutations in CCND1 is associated with increased risk of breast cancer (Soleimani et al. 2017). A previous study demonstrated that overexpression of CCND1 has occurred through amplification, translocation, or post-transcriptional regulation (Xu and Lin 2018). CCND1 gene amplification is a molecular key alteration in breast cancer and was suggested to predict resistance to endocrine therapy (Kilker et al. 2004). Taken together, gene amplification of CCND1 possibly plays an essential role in cisplatin-resistant TNBC. This mechanism needs to be explored further.

The results of this present study revealed that CCND1 is downregulated in cisplatin-resistant TNBC. A previous study demonstrated that targeting CCND1 with miR-503 leads to the induction of G0/G1 cell cycle arrest and reduction of cell proliferation in breast cancer (Long et al. 2015). Another study showed that downregulation of cyclin D1 inhibits proliferation and colony formation in SKOV3 ovarian cancer the cells (Yang et al. 2017). In addition, inhibition of proliferation in human ovarian cancer cells by cisplatin is correlated with inhibition of CCND1 expression (Dai et al. 2016). miR-638 targets CCND1 and thus inactivates PI3K/Akt pathway-regulated cell growth in Sertoli cells (Hu et al. 2017). Therefore, further studies on the role of CCND1 in TNBC resistance mechanism to cisplatin are needed.

FZD7 encodes frizzled homolog 7 (Yang et al. 2011) and plays an important role as a membrane receptor in Wnt/ $\beta$-catenin signaling in cancer cells (Xie et al. 2018). Wnt signaling is activated in TNBC (King et al. 2012). The expression of FZD7 is upregulated in patients with breast cancer compared to normal tissues (Jia et al. 2018). In addition, inhibition of FZD7 with interfering RNA (King et al. 2012; Yang et al. 2011) or monoclonal antibody (Zarei et al. 2018) could reduce cell proliferation in TNBC. Recently, FZD7 is targeted by miR-638, leading to inhibition of Wnt signaling in glioma progression (Chen and Duan 2018). Therefore, it is necessary to further investigate the role of FZD7 in the mechanism of cisplatin resistance in TNBC. Further, in vitro and in vivo studies need to be done on the mechanism of miR-638 regulat- ing cisplatin resistance in TNBC, as well as how miR-638 regulates its target gene.

\section{Conclusions}

Our study provides an integrated data mining analysis of the cisplatin resistance association between miR-638 with the overall survival of breast cancer patients. miR-638 plays a role in cisplatin resistance mechanism through a mechanism involving its target genes CCND1 and FZD7. This present study also identifies miR-638 and its target genes (CCND1 and FZD7) as a key gene and the potential biomarker of cisplatin resistance in TNBC. However, further in vitro and in vivo validation is needed to develop the target gene as a biomarker.

\section{Authors' contributions}

$\mathrm{AH}$ - conception and design of the study, acquisition, analysis and interpretation of data, drafting and revising the article and final approval of the version to be published, HP-acquisition and analysis of data, drafting the article and final approval of the version to be published. All authors read and approved the final version of the manuscript.

\section{Competing interests}

The authors declare no competing interest.

\section{References}

Agarwal V, Bell GW, Nam JW, Bartel DP. 2015. Predicting effective microRNA target sites in mammalian mRNAs. eLife 4. doi:10.7554/eLife.05005.

Baykara O, Dalay N, Bakir B, Bulut P, Kaynak K, Buyru N. 2017. The EMSY gene collaborates with CCND1 in non-small cell lung carcinogenesis. Int J Med Sci 14(7):675-679. doi:10.7150/ijms.19355.

Bhattacharya A, Schmitz U, Raatz Y, Schonherr M, Kottek T, Schauer M, Franz S, Saalbach A, Anderegg U, Wolkenhauer O, et al. 2015 . miR-638 promotes melanoma metastasis and protects melanoma cells from apoptosis and autophagy. Oncotarget 6(5):2966-2980. doi:10.18632/oncotarget.3070.

Burandt E, Grünert M, Lebeau A, Choschzick M, Quaas A, Jänicke F, Müller V, Scholz U, Bokemeyer C, Petersen C, et al. 2016. Cyclin D1 gene amplification is highly homogeneous in breast cancer. Breast Cancer 23(1):111-119. doi:10.1007/s12282-014-0538-y.

Cerami E, Gao J, Dogrusoz U, Gross BE, Sumer SO, Aksoy BA, Jacobsen A, Byrne CJ, Heuer ML, Larsson E, et al. 2012. The cBio cancer genomics portal: an open platform for exploring multidimensional cancer genomics data. Cancer Discovery 2(5):401-404. doi:10.1158/2159-8290.cd-12-0095. 
Chen Z, Duan X. 2018. hsa_circ_0000177-miR-638FZD7-Wnt signaling cascade contributes to the malignant behaviors in glioma. DNA and Cell Biol 37(9):791-797. doi:10.1089/dna.2018.4294.

Dai J, Wei RJ, Li R, Feng JB, Yu YL, Liu PS. 2016. A study of CCND1 with epithelial ovarian cancer cell proliferation and apoptosis. Eur Rev Med Pharmacol Sci 20(20):4230-4235.

Fuste NP, Castelblanco E, Felip I, Santacana M, Fernandez-Hernandez R, Gatius S, Pedraza N, Pallares J, Cemeli T, Valls J, et al. 2016. Characterization of cytoplasmic cyclin D1 as a marker of invasiveness in cancer. Oncotarget 7(19):26979-26991. doi:10.18632/oncotarget.8876.

Gao J, Aksoy BA, Dogrusoz U, Dresdner G, Gross B, Sumer SO, Sun Y, Jacobsen A, Sinha R, Larsson E, et al. 2013. Integrative analysis of complex cancer genomics and clinical profiles using the cBioPortal. Sci Signaling 6(269):pl1. doi:10.1126/scisignal.2004088.

Garnett MJ, Edelman EJ, Heidorn SJ, Greenman CD, Dastur A, Lau KW, Greninger P, Thompson IR, Luo X, Soares J, et al. 2012. Systematic identification of genomic markers of drug sensitivity in cancer cells. Nature 483(7391):570-575. doi:10.1038/nature11005.

Gyorffy B, Lanczky A, Eklund AC, Denkert C, Budczies J, Li Q, Szallasi Z. 2010. An online survival analysis tool to rapidly assess the effect of 22,277 genes on breast cancer prognosis using microarray data of 1,809 patients. Breast Cancer Res Treat 123(3):725731. doi:10.1007/s10549-009-0674-9.

Gyorffy B, Surowiak P, Kiesslich O, Denkert C, Schafer R, Dietel M, Lage H. 2006. Gene expression profiling of 30 cancer cell lines predicts resistance towards 11 anticancer drugs at clinically achieved concentrations. Int J Cancer 118(7):1699-1712. doi:10.1002/ijc.21570.

He M, Lin Y, Tang Y, Liu Y, Zhou W, Li C, Sun G, Guo M. 2016. miR-638 suppresses DNA damage repair by targeting SMC1A expression in terminally differentiated cells. Aging 8(7):1442-1456. doi:10.18632/aging.100998.

Hu P, Guan K, Feng Y, Ma C, Song H, Li Y, Xia X, Li J, Li F. 2017. miR-638 Inhibits immature Sertoli cell growth by indirectly inactivating PI3K/AKT pathway via SPAG1 gene. Cell Cycle 16(23):22902300. doi:10.1080/15384101.2017.1380130.

Hu XC, Zhang J, Xu BH, Cai L, Ragaz J, Wang ZH, Wang BY, Teng YE, Tong ZS, Pan YY, et al. 2015. Cisplatin plus gemcitabine versus paclitaxel plus gemcitabine as first-line therapy for metastatic triplenegative breast cancer (CBCSG006): a randomised, open-label, multicentre, phase 3 trial. Lancet Oncol 16(4):436-446. doi:10.1016/s1470-2045(15)700641.

Ji X, Lu Y, Tian H, Meng X, Wei M, Cho WC. 2019. Chemoresistance mechanisms of breast cancer and their countermeasures. Biomed Pharmacother 114:108800. doi:10.1016/j.biopha.2019.108800.
Jia XP, Meng LL, Fang JC, Wang HW, Chen J, Zhou J, Wang CN, Jiang WF. 2018. Aberrant expression of miR-142-3p and its target gene HMGA1 and FZD7 in breast cancer and its clinical significance. Clin Lab 64(6):915-921. doi:10.7754/Clin.Lab.2017.171114.

Kilker RL, Hartl MW, Rutherford TM, Planas-Silva MD. 2004. Cyclin D1 expression is dependent on estrogen receptor function in tamoxifen-resistant breast cancer cells. J Steroid Biochem Mol Biol 92(1-2):63-71. doi:10.1016/j.jsbmb.2004.05.005.

Kim C, Gao R, Sei E, Brandt R, Hartman J, Hatschek T, Crosetto N, Foukakis T, Navin NE. 2018. Chemoresistance evolution in triple-negative breast cancer delineated by single-cell sequencing. Cell 173(4):879893.e13. doi:10.1016/j.cell.2018.03.041.

King TD, Suto MJ, Li Y. 2012. The Wnt/beta-catenin signaling pathway: a potential therapeutic target in the treatment of triple negative breast cancer. J Cell Biochem 113(1):13-18. doi:10.1002/jcb.23350.

Kuo WY, Hwu L, Wu CY, Lee JS, Chang CW, Liu RS. 2017. STAT3/NF-kappaB-regulated lentiviral TK/GCV suicide gene therapy for cisplatin-resistant triple-negative breast cancer. Theranostics 7(3):647663. doi:10.7150/thno.16827.

Lee JK, Havaleshko DM, Cho HJ, Weinstein JN, Kaldjian EP, Karpovich J, Grimshaw A, Theodorescu D. 2007. A strategy for predicting the chemosensitivity of human cancers and its application to drug discovery. Proc Natl Acad Sci 104(32):13086-13091. doi:10.1073/pnas.0610292104.

Lefebvre C, Bachelot T, Filleron T, Pedrero M, Campone M, Soria JC, Massard C, Levy C, Arnedos M, Lacroix-Triki M, et al. 2016. Mutational profile of metastatic breast cancers: a retrospective analysis. PLoS Med 13(12):e1002201. doi:10.1371/journal.pmed.1002201.

Li D, Wang Q, Liu C, Duan H, Zeng X, Zhang B, Li X, Zhao J, Tang S, Li Z, et al. 2011. Aberrant expression of miR-638 contributes to benzo(a)pyrene-induced human cell transformation. Toxicol Sci 125(2):382391. doi:10.1093/toxsci/kfr299.

Lin Y, Li D, Liang Q, Liu S, Zuo X, Li L, Sun X, Li W, Guo M, Huang Z. 2015. miR-638 regulates differentiation and proliferation in leukemic cells by targeting cyclindependent kinase 2. J Biol Chem 290(3):1818-1828. doi:10.1074/jbc.M114.599191.

Long J, Ou C, Xia H, Zhu Y, Liu D. 2015. MiR-503 inhibited cell proliferation of human breast cancer cells by suppressing CCND1 expression. Tumor Biol 36(11):8697-8702. doi:10.1007/s13277-015-3623-8.

Maia LBL, Breginski FSC, Cavalcanti TCS, de Souza RLR, Roxo VMS, Ribeiro EMSF. 2016. No difference in CCND1 gene expression between breast cancer patients with and without lymph node metastasis in a Southern Brazilian sample. Clin Exp Med 16(4):593-598. doi:10.1007/s10238-015-0392-z.

Oliveros JC. 2007. Venny. An interactive tool for comparing lists with Venn's diagrams URL http://bioinfogp. 
cnb.csic.es/tools/venny/index.html.

Orso F, Quirico L, Dettori D, Coppo R, Virga F, Ferreira LC, Paoletti C, Baruffaldi D, Penna E, Taverna D. 2019. Role of miRNAs in tumor and endothelial cell interactions during tumor progression. Semin Cancer Biol doi:10.1016/j.semcancer.2019.07.024.

Pandika M. 2018. Mining Gene Expression Data for Drug Discovery. ACS Cent Sci 4(8):944-947. doi:10.1021/acscentsci.8b00529.

Ramos-Garcia P, Gil-Montoya JA, Scully C, Ayen A, Gonzalez-Ruiz L, Navarro-Trivino FJ, GonzalezMoles MA. 2017. An update on the implications of cyclin D1 in oral carcinogenesis. Oral Dis 23(7):897912. doi:10.1111/odi.12620.

Ren Y, Chen Y, Liang X, Lu Y, Pan W, Yang M. 2017. MiRNA-638 promotes autophagy and malignant phenotypes of cancer cells via directly suppressing DACT3. Cancer Lett 390:126-136. doi:10.1016/j.canlet.2017.01.009.

Rhodes DR, Yu J, Shanker K, Deshpande N, Varambally R, Ghosh D, Barrette T, Pandey A, Chinnaiyan AM. 2004. ONCOMINE: a cancer microarray database and integrated data-mining platform. Neoplasia 6(1):1-6. doi:10.1016/S1476-5586(04)800472.

Seiler R, Thalmann GN, Rotzer D, Perren A, Fleischmann A. 2014. CCND1/CyclinD1 status in metastasizing bladder cancer: a prognosticator and predictor of chemotherapeutic response. Mod Pathol 27(1):87-95. doi:10.1038/modpathol.2013.125.

Shannon P, Markiel A, Ozier O, Baliga NS, Wang JT, Ramage D, Amin N, Schwikowski B, Ideker T. 2003. Cytoscape: a software environment for integrated models of biomolecular interaction networks. Genome Res 13(11):2498-504. doi:10.1101/gr.1239303.

Shen Y, Chen H, Gao L, Zhang W, He J, Yang X, Qin L, Xue X, Guo Z. 2017. MiR-638 acts as a tumor suppressor gene in gastric cancer. Oncotarget 8(64):108170-108180. doi:10.18632/oncotarget.22567.

Silver DP, Richardson AL, Eklund AC, Wang ZC, Szallasi Z, Li Q, Juul N, Leong CO, Calogrias D, Buraimoh A, et al. 2010. Efficacy of neoadjuvant Cisplatin in triplenegative breast cancer. J Clin Oncol 28(7):1145-53. doi:10.1200/jco.2009.22.4725.

Soleimani Z, Kheirkhah D, Sharif MR, Sharif A, Karimian M, Aftabi Y. 2017. Association of CCND1 gene c.870G $>$ A polymorphism with breast cancer risk: a case-control study and a meta-analysis. Pathol Oncol Res 23(3):621-631. doi:10.1007/s12253-016-01653.

Tan X, Peng J, Fu Y, An S, Rezaei K, Tabbara S, Teal CB, Man YG, Brem RF, Fu SW. 2014. miR638 mediated regulation of BRCA1 affects DNA repair and sensitivity to UV and cisplatin in triplenegative breast cancer. Breast Cancer Res 16(5):435. doi:10.1186/s13058-014-0435-5.
Ullah Shah A, Mahjabeen I, Kayani MA. 2015. Genetic polymorphisms in cell cycle regulatory genes CCND1 and CDK4 are associated with susceptibility to breast cancer. J Buon 20(4):985-993.

Wang F, Lou JF, Cao Y, Shi XH, Wang P, Xu J, Xie EF, Xu T, Sun RH, Rao JY, Huang PW, Pan SY, Wang H. 2015. miR-638 is a new biomarker for outcome prediction of non-small cell lung cancer patients receiving chemotherapy. Exp Mol Med 47:e162. doi:10.1038/emm.2015.17.

Wang Y, Ren F, Li B, Song Z, Chen P, Ouyang L. 2019. Ellagic acid exerts antitumor effects via the PI3K signaling pathway in endometrial cancer. J Cancer 10(15):3303-3314. doi:10.7150/jca.29738.

Wei H, Zhang JJ, Tang QL. 2017. MiR-638 inhibits cervical cancer metastasis through Wnt/betacatenin signaling pathway and correlates with prognosis of cervical cancer patients. Eur Rev Med Pharmacol Sci 21(24):5587-5593. doi:10.26355/eurrev_201712_13999.

Wei L, Wang X, Lv L, Zheng Y, Zhang N, Yang M. 2019. The emerging role of noncoding RNAs in colorectal cancer chemoresistance. Cell Oncol (Dordr) pages 112. doi:10.1007/s13402-019-00466-8.

Xiao F, Zuo Z, Cai G, Kang S, Gao X, Li T. 2009. miRecords: an integrated resource for microRNA-target interactions. Nucleic Acids Res 37(suppl_1):D105-D110. doi:10.1093/nar/gkn851.

Xie W, Zhang Y, He Y, Zhang K, Wan G, Huang Y, Zhou Z, Huang G, Wang J. 2018. A novel recombinant human Frizzled-7 protein exhibits anti-tumor activity against triple negative breast cancer via abating Wnt/beta-catenin pathway. Int J Biochem Cell Biol 103:45-55. doi:10.1016/j.biocel.2018.08.004.

$\mathrm{Xu}$ J, Lin DI. 2018. Oncogenic c-terminal cyclin D1 (CCND1) mutations are enriched in endometrioid endometrial adenocarcinomas. PLoS One 13(7):e0199688 1-14. doi:10.1371/journal.pone.0199688.

Xu J, Wan X, Chen X, Fang Y, Cheng X, Xie X, Lu W. 2016. miR-2861 acts as a tumor suppressor via targeting EGFR/AKT2/CCND1 pathway in cervical cancer induced by human papillomavirus virus 16 E6. Sci Rep 6(1):28968 1-14. doi:10.1038/srep28968.

Xue M, Shen J, Cui J, Wu J, Qiao W, Ding N, Song C, Shan B. 2019. MicroRNA-638 expression change in osteosarcoma patients via PLD1 and VEGF expression. Exp Ther Med 17(5):3899-3906. doi:10.3892/etm.2019.7429.

Yang L, Wu X, Wang Y, Zhang K, Wu J, Yuan YC, Deng X, Chen L, Kim CC, Lau S, et al. 2011. FZD7 has a critical role in cell proliferation in triple negative breast cancer. Oncogene 30(43):4437-4446. doi:10.1038/onc.2011.145.

Yang Z, Feng Z, Gu JH, Li XH, Dong QZ, Liu KR, Li Y, OuYang L. 2017. microRNA-488 inhibits chemoresistance of ovarian cancer cells by targeting Six1 and mitochondrial function. Oncotarget 8(46):80981- 
80993. doi:10.18632/oncotarget.20941.

Zarei N, Fazeli M, Mohammadi M, Nejatollahi F. 2018.

Cell growth inhibition and apoptosis in breast cancer cells induced by anti-FZD7 scFvs: involvement of bioinformatics-based design of novel epitopes. Breast Cancer Res Treat 169(3):427-436. doi:10.1007/s10549-017-4641-6.

Zhao B, Erwin A, Xue B. 2018. How many differentially expressed genes: A perspective from the comparison of genotypic and phenotypic distances. Genomics 110(1):67-73. doi:10.1016/j.ygeno.2017.08.007.

Zheng DH, Wang X, Lu LN, Chen DL, Chen JM, Lin FM, Xu XB. 2018. MiR-638 serves as a tumor suppressor by targeting HOXA9 in glioma. Eur Rev Med Pharmacol Sci 22(22):7798-7806. doi:10.26355/eurrev_201811_16404. 